\title{
TRADICIONAL, MODERNO E CONTEMPORÂNEO ${ }^{1}$
}

Laymert Garcia dos Santos

Boa noite, eu queria começar agradecendo ao convite para participar deste primeiro Fórum do Programa de Pós-Graduação em Sociologia, e principalmente aos organizadores e ao professor Pedro, que não está presente aqui, mas eu sei que virtualmente está presente numa sala do Ciclo Básico com a sua turma de estudantes de Engenharia. Então boa noite Pedro também, aí à distância.

O Pedro me convidou para fazer uma fala aqui, e eu estou aposentado já, desde o ano passado, e depois que eu me aposentei eu voltei poucas vezes à Universidade, em geral só para algumas bancas de teses, então eu me dei conta de que eu até que estou meio perdendo a mão para fazer palestra, para falar, fazer uma fala acadêmica. Já estou de certo modo desconectando da Universidade, então senti certa dificuldade em organizar meu pensamento para falar aqui hoje, mas como o Pedro me apertava, inclusive para dar um título para esta intervenção, eu não sei por que eu dei o título que é Tradicional, Moderno e Contemporâneo. Eu acho que, como uma espécie de pano de fundo desse enunciado que veio na minha

\footnotetext{
1 Este artigo foi originalmente exposto em uma conferência apresentada pelo professor Laymert Garcia Santos dia 27 de maio de 2014, na ocasião do encerramento do $1^{\circ}$ Fórum do Programa de Pós-Graduação em Sociologia do Instituto de Filosofia e Ciências Humanas da Universidade Estadual de Campinas. Agradecemos ao professor Laymert pela oportunidade de poder publicar aqui sua apresentação. Agradecemos também a Lucas Mestrinelli pela transcrição da entrevista.
} 
cabeça, existe uma espécie de condição atual, uma espécie de situação e condição atuais, que fazem com que esses três termos apareçam de modo muito novo, de certa maneira, e apareçam também com um sentido que não é mais o sentido que a gente normalmente costumava atribuir a esses termos até não muito tempo.

Eu falo não muito tempo, mas evidentemente esse não muito tempo para mim não é muito tempo, mas é a década de 1970 que foi quando tudo começou a mudar de uma maneira violenta. Para vocês, evidentemente, 1970 é muito tempo, porque a maioria das pessoas aqui deve ter nascido bem depois disso, e já nasceram com a internet na frente. Então já é uma situação que eu justamente gostaria de caracterizar, porque já nasceram num mundo onde a tecnologia já havia se tornado uma espécie de segunda natureza. Tem a primeira natureza, que é a natureza que a gente comumente pensa que é, tem a segunda natureza que é toda essa esfera tecnicizada e tecnologizada na qual a gente vive hoje, e com a qual esse meio sociotécnico com o qual a gente convive diariamente, que é imprescindível para nós, e que a gente considera quase de certo modo, como dado, como fazendo parte, como se estivesse sempre existido, sempre estivesse estado aí. E é um pouco sobre isso que eu quero falar porque é justamente essa condição de viver num mundo em que existe uma primeira e uma segunda natureza e que a primeira natureza está cada vez mais distante e ela é cada vez mais mediada pela segunda natureza, isso muda nossa maneira de perceber as coisas, muda nossa maneira de pensar, muda nossa maneira de existir.

No entanto (e aí vai uma provocação), parece que as ciências sociais, como disciplinas que são do século XIX de certo modo, ainda não se deram conta completamente do alcance que essa mudança trouxe, e do impacto que essa mudança tem para a própria disciplina Sociologia. Por que eu estou falando isso? Eu estou falando isso porque de certo modo eu sou de uma das primeiras gerações de gente que se auto-intitulou, no campo da Sociologia, como alguém que trabalha com Sociologia da Tecnologia. Isso quando eu entrei aqui no IFCH, por exemplo, não existia, e hoje isso é um campo dentro da Sociologia bastante trabalhado já, e que vai adquirindo com o passar do tempo uma centralidade cada vez maior, porque justamente não dá pra gente não pensar em termos sociotécnicos 
essas mudanças que começaram a acontecer de um modo radical na década de 1970 e daí pra frente essas mudanças só vieram a acelerar de uma maneira cada vez mais intensa.

Porque eu dato 1970? Porque 1970 é a década em que uma boa parte das chamadas tecnologias da informação saiu dos laboratórios, saiu do campo da experimentação e entrou em todos os campos sociais, entrou, penetrou, na sociedade em todos os campos. Ganhou, por exemplo, a vida cotidiana das pessoas, entrou na linguagem, entrou no trabalho, com repercussões cada vez maiores. Começou na década de 1970 essa espécie de tecnologização forte da sociedade no exato momento em que começou uma coisa que se chama Lei de Moore, que é um indicador da velocidade de mudança tecnológica. A Lei de Moore é uma lei que determina, (desde 1970 pra cá, ou seja, há mais de 40 anos, e ela continua valendo), que a cada 18 meses a capacidade e a potência de cálculo dos computadores e das máquinas eletrônicas duplicam. Quer dizer, ela vem duplicando a cada 18 meses desde o começo da década de 1970, o que significa, digamos, uma velocidade de potência de cálculo absolutamente vertiginosa. Se a gente pegar como que era um computador no começo da década de 1970 e como que é hoje, o do começo da década de 1970, aquilo que hoje a gente tem como potência de cálculo no laptop era preciso de uma sala de computação de quase metade do tamanho desta daqui. Para ter a mesma potência de cálculo, que significava justamente então que, primeiro, já não existia computador portátil, é claro; segundo que pouquíssimas instituições tinham; terceiro que era caríssimo e, portanto o acesso aos computadores era muito restrito. De lá pra cá, justamente se pôde fazer aquilo que um inventor americano, Buckminster Fuller, chamou de miniaturização.

Com a miniaturização dos anos 1970 pra cá foi possível fazer cada vez mais com menos. Mais com menos energia, mais com menos tempo, mais com menos trabalho. O que é de certo modo uma coisa meio paradoxal, fazer mais com menos, mas isso é um dado de realidade que permite a gente pensar justamente o sentido desta transformação. O Buckmister aponta duas tendências importantes convergentes, na década de 1970, que fazem aquilo que eu chamo de virada cibernética, ou seja, virada informacional, e que para mim muda tudo, sobretudo a 
relação tradicional-moderno-contemporâneo. Ele diz que de um lado houve a miniaturização, e de outro lado havia uma aceleração tecnológica que vinha desde o século XIX, em que as máquinas permitiam fazer mais coisas em menos tempo, ou seja, desde a Primeira Revolução Industrial. Mas quando chegou a Terceira Revolução Industrial, que é a Revolução Cibernética, e que ela ganhou todos os campos da atividade humana a partir da década de 1970, houve um salto, diz o Buckmister Fuller, este salto se caracteriza por algo que ele chamou de efemerelização, que é uma aceleração da aceleração.

Quer dizer, vinha a tecnologia, a evolução tecnológica vinha acelerando de intensidade do século XIX em diante, e a partir da década de 1970 do século passado, houve uma aceleração da aceleração, isso significa uma aceleração exponencial, que na linguagem dos cientistas que trabalham com foguete significa velocidade de escape. Velocidade de escape é quando um foguete é lançado no espaço, durante certo tempo ele ainda está sob o efeito gravitacional da Terra, então ele tem que lutar contra esse efeito até um determinado momento em que ele sai da atmosfera terrestre e ganha velocidade de escape porque não tem mais nenhuma força que o contenha. Então o foguete se manda para o espaço em velocidade de escape porque ele escapa da força da gravidade e nada mais pode segurá-lo no seu impulso, no seu movimento.

A década de 1970 representou justamente a velocidade da tecnologia informacional, e com ela da tecnologização da sociedade como um todo. E é por isso que os parâmetros todos nossos, e inclusive os parâmetros conceituais sociológicos que vinham do século XIX e que regravam o entendimento da sociedade e dos fenômenos sociais, do fato social e etc. É por isso que a partir da década de 1970, esses conceitos começaram a sofrer um abalo bastante grande e começaram, digamos, e nós começamos, não só os cientistas sociais, mas a experiência humana como tal, começou todo mundo a perder o pé. Perder o pé significa algo como os valores e os conceitos modernos que pensavam a sociedade moderna não valem mais. Ou melhor, eles valem, eles continuam valendo, mas de certo modo restrito, ou eles valem à luz de alguma outra coisa, e é aí que eu faço a diferença entre moderno e contemporâneo. Moderno vem do século 
XIX até 1970, e o contemporâneo, para mim, começa na década de 1970 porque justamente os parâmetros para se entender o que é que está acontecendo (que é o que interessa), mudaram. Mudaram e começaram a mudar de modo cada vez mais violento, tão violento que há gente que diz que nós vivemos numa situação na qual a gente vive sob uma ditadura do tempo, ninguém mais tem tempo, todo mundo corre atrás do prejuízo permanentemente, em qualquer lugar do planeta, e o fato de ninguém mais ter tempo não vai melhorar.

A gente tem máquinas que são cada vez mais velozes para nos ajudarem a lidar com essa falta de tempo, e, no entanto parece que quanto mais velozes elas são, isto é um paradoxo, parece que a gente tem menos tempo ainda, por exemplo: hoje em dia, se a gente pensa o que era fazer uma tese de doutorado, ou vocês que estão no programa de pós-graduação, pensem no que era fazer uma pesquisa bibliográfica antes da internet. Você tinha a biblioteca do IFCH, que não era isso que é hoje, e quando você precisava de uma informação que não estava na biblioteca do IFCH, você esperava, ou você importava o livro, ou você esperava um tempo enorme para conseguir acessar as informações, para conseguir acessar os textos, e hoje vocês sabem, quando a gente vai fazer o download de uma tese de doutorado que a gente descobriu que está estudando o mesmo assunto que a gente está estudando, alguém que defendeu nos EUA ou na França, ou mesmo defendeu em outra universidade brasileira, você descobre pela internet que também tem aquela pessoa, coisa que antigamente você nem ficava sabendo. Em geral anos depois você descobre que aquele assunto que você tinha escolhido alguém já escolheu, já defendeu a tese lá não sei aonde. E aí quando você vai pedir para fazer o download dessa tese, se demorar mais do que dois minutos você já não tem mais paciência, você já acha que está demorando demais, para baixar em dois ou três minutos aquilo. E o problema não vai ser o acesso, fazer baixar, porque o acesso é facílimo, o problema vai ser o tempo que você vai arranjar ou o tempo que você vai conseguir para ler todo esse material. Você pode acessar, e eu estou cansado de ver uma porção de gente acessando bibliografias gigantescas, e dessa bibliografia só há possibilidade de leitura de um décimo, quando muito. E aí o critério não é mais o de você ter à sua mão toda aquela 
variedade de materiais, é saber como selecionar esses materiais, a questão não é mais do acesso, a questão é do filtro, saber como filtrar aquilo, e em geral as pessoas ficam neuróticas porque elas não tem tempo, elas acham que precisavam ler tudo, e elas não tem tempo de ler tudo, e ainda tem o programa de produtividade atrás dela pressionando, e mais os professores pressionando, e todo mundo pressionando que ao mesmo tempo você tem que ir ao Congresso, que você tem que fazer o paper, que você tem que fazer não sei o que lá, que você tem que mostrar que é produtivo em tempo record e etc. Então, portanto, ninguém mais tem tempo.

Agora eu tenho tempo, por exemplo, porque me aposentei, então é uma maravilha porque se eu quiser ficar dez dias para ler uma tese, para ler um capítulo a cada três dias eu posso, mas eu já estou fora do sistema, então eu só posso porque estou fora do sistema e eu não tenho mais que preencher meu currículo lattes, a partir do dia que eu me aposentei, pronto, eu não preenchi mais nada, tudo que eu fiz depois eu já não botei no Lattes. Só vai ficar sabendo quem eu quiser que fique sabendo. Eu não tenho mais que obedecer ao preenchimento do currículo Lattes e isto faz uma diferença, é claro, e eu estou puxando esse exemplo para mostrar pra vocês que essa ditadura do tempo é uma coisa real e é uma coisa que afeta a vida das pessoas e que vai afetar cada vez mais.

Ela afeta a ponto de, por exemplo, no mercado financeiro quando tem crise, (isso desde a crise de 1929 já era sim, que era uma crise velhíssima), os investidores quando viram que as ações estavam despencando, eles telefonavam para os operadores, ou mandavam email, e eles diziam três letras, que era GMO, que quer dizer Get me Out, me tire desta. Eles escreviam GMO porque escrever Get me Out, olha o tamanho da frase, são três palavrinhas deste tamanho, era tempo demais, porque se você fala GMO você perde menos dinheiro do que Get me Out, que quando você acabou o Out você já perdeu tantos milhões. Então isso dá uma ideia do que é uma economia em tempo real, uma especulação em tempo real, e a questão de que não há mais tempo, isto tudo é evidentemente um problema real.

Há um dramaturgo, e é interessante que seja um dramaturgo, um escritor e poeta e não seja um teórico, um sociólogo, que escreveu 
uma coisa muito interessante para caracterizar o que é esse tempo desta velocidade. Ele diz que foram os nazistas que inventaram uma coisa que ele chamou de estratégia de aceleração total econômica e tecnológica. Foram os nazistas que inventaram isso, essa estratégia, porque os nazistas sabiam muito, conheciam muito intensamente a tecnologia como arma, a tecnologia com um sentido de predação e de exercício de poder a qualquer preço. E por isso mesmo eles bolaram essa estratégia, que não acabou com o fim do nazismo, ao contrário, ela se intensificou depois do fim do nazismo, e aceleração total econômica e tecnológica vai engatar nessa aceleração da aceleração que eu estava falando da década de 1970 e vai ser, digamos, o fio central, o motor, de um tipo de tecnologização da sociedade que faz com que ninguém mais tenha tempo e que a gente viva sob a ditadura do tempo. O próprio Heiner Müller diz uma frase que eu vou ler, e que eu acho interessantíssima, ele diz assim: "O que de pior acontece no momento é que só há tempo ou velocidade ou passagem de tempo, mas não há espaço, é preciso criar espaço e ocupá-los contra essa aceleração. Só aí pode vir a cultura de um espaço que reaja à ditadura do tempo sem tempo".

Do tempo sem tempo é uma coisa interessante, eu acho que ele diz justamente que em um processo como este o que aconteceu foi que o espaço acabou, acabou justamente porque o espaço se transformou, já desde Einsten no espaço-tempo, mas, sobretudo sobre a ditadura de um tempo sem tempo. E sendo assim, a maneira de lutar contra a aceleração vai ser justamente de abrir espaço onde não existe mais espaço. Mas a gente vai falar: como que não existe mais espaço?

Uma das maneiras da gente perceber que não existe mais espaço é que o espaço se contraiu de tal maneira que eu posso me comunicar com qualquer lugar do planeta em tempo real. Quer dizer, eu posso fazer, digamos, quando eu abro aquela janela $W$ indows, que é uma janela que eu penso justamente que o mundo chega até a mim suprimindo justamente o espaço, porque eu abro a janela Windows e eu posso acessar alguma coisa que está acontecendo em Pequim em tempo real dentro do meu escritório. Eu não penso, que quando eu faço isso eu faço a operação inversa também, quer dizer, que eu abro a janela Windows e que ao mesmo 
tempo em que o mundo chega até a mim eu saio de mim e vou para este mundo, e ao fazer essa operação na verdade o Windows é uma interface que está abolindo justamente a presença espacial. Você não precisa mais sair do lugar para conhecer os lugares, e o mais paradoxal disso é que quando você sai, até pagando para ir conhecer outros lugares, você chega ao outro lugar e você não vê o lugar porque você pega seu celular e fica fotografando o lugar, quer dizer que você vê aquele lugar exatamente da mesma maneira que você não precisava nem ter ido lá pra ver, porque você já podia ver acessando pelo seu computador, só que você não se dá conta de que você saiu do seu lugar e foi para o outro lugar para repetir a abolição do espaço e a abolição do lugar porque você só vai ver aquele outro lugar mediado por um aparelho que vai justamente te permitir ver depois, e não no momento em que você está lá. Ou seja, a presença do espaço e você naquele espaço não conta, porque você está ali, mas você só está ali para bater a foto que testemunha que você esteve ali, mas que você só vai ver depois, portanto você não está ali, você está depois, você está antecipando aquilo que você vai ver depois e que você acha que seus amigos vão ver, vão ter interesse em ver, mas depois você descobre também que eles não tem o menor interesse porque eles também fizeram a mesma operação que você e quando você for passar os slides pra eles, eles vão achar um porre os seus slides, porque eles também só estão vendo os slides deles, que aquilo só interessa pra você, porque não tem experiência nenhuma do contato com o lugar, o contato com o lugar acabou.

Eu estou dizendo isso tudo, quero que entendam bem, que eu não sou contra tecnologia, quero deixar isso muito bem claro, eu estou apenas problematizando algumas questões para mostrar a vocês que a gente vive num mundo que é muito diferente do mundo como era no século XIX ou mesmo na primeira metade do século XX ou até 1960, eu era adulto, e eu fazia faculdade na década de 1960 . Não é o mesmo mundo hoje do que o mundo de quando eu fiz a faculdade. A faculdade não é a mesma, a universidade não é a mesma e nada mais é o mesmo, a experiência cotidiana não é a mesma, e o modo de existir das pessoas, e de pensar também não é mais o mesmo. Não interessa saber se é melhor ou pior, é 
diferente, quando o Heiner Müller diz que não há mais espaço, mas não é só ele que diz isso.

Há um arquiteto famoso e teórico também desses meios chamado Paul Virilio, ele também diz que os espaços começam a dar trombada, e que justamente numa situação de trombada fica a experiência do espaço digamos "real", ele chama de espaço "real", mas a gente nem pode mais falar espaço real porque o espaço virtual é tão real quanto o espaço atual. Aqui nós estamos num espaço atual, mas a gente pode, se vocês, por exemplo, começarem a se encher com o que eu estou falando, vocês podem puxar o seu computador, o seu celular e começar a acessar seus emails e vocês já não estão mais aqui, vocês estão no espaço virtual, vocês só estão digamos só a casca de vocês está aqui na minha presença, mas vocês já estão no espaço virtual, e vocês podem estar nos dois espaços ao mesmo tempo, mas aqui só, digamos, fazendo figuração, se a gente pudesse dizer assim. Vocês estão mesmo é no outro espaço. Então isso mostra pra gente que esse tipo de experiência é uma experiência muito forte e que é preciso, sobretudo na área de Ciências Sociais, pensar que efeitos isso tem sobre a existência, sobre a produção de conhecimento, e que efeitos isso tem também sobre trabalho, linguagem, vida, e que efeitos isso tem sobre todos os aspectos da experiência humana, a começar pela percepção.

É claro que existe uma metamorfose violenta da percepção. A percepção da gente não é mais a mesma, se eu posso fazer minha trilha sonora passeando pela floresta amazônica, se eu posso ficar ouvindo Wagner dentro do meu aparelhinho ou dentro do meu celular em plena floresta amazônica, e faço minha trilha sonora no meu passeio na floresta é claro que essa experiência não é a mesma experiência do homem do século XVIII que só podia ouvir a música na Igreja ou no Palácio, ou no dia que tivesse uma festa popular, ou então ele sabia tocar piano ou tocar o violino e ele conhecia partitura e ele podia ouvir mentalmente, só lendo a partitura, aquilo que se passava dentro da cabeça dele, ele tocava a música dentro da cabeça dele. Hoje eu não preciso saber nada disso, eu posso escolher minha trilha sonora para qualquer situação que eu quiser. 
Parece um "filme", justamente, a gente entra, digamos, dentro da imagem, no final das contas.

Há um comentário interessante sobre o que o Virilio faz, sobre essa estratégia de aceleração total, econômica e tecnológica, e ele diz o seguinte, (e isso ele diz que foram os nazistas que inventaram também): a estratégia tem que ser total e quando ela é total, ela é totalitária, é claro, ou seja, o trem bala tem certa velocidade, e ele impõe essa velocidade para todas as pessoas indiscriminadamente. Há as pessoas que estão no trem, há as pessoas que querem entrar no trem, há as pessoas que estavam no trem e que não querem estar no trem, há as pessoas que não conseguem ficar no trem. Quer dizer, você tem uma série de situações, e ele diz, algo que eu acho que é muito interessante, e que tem a ver com o tradicional moderno e contemporâneo, e tem a ver também com essa questão do espaço, porque ele diz o seguinte, se a aceleração é total, e se há uma estratégia de aceleração total econômica e tecnológica, ou você gruda na locomotiva do trem, ou você dançou.

Querendo ou não querendo, existem populações que não querem estar no trem, e que ficam do lado de fora, elas vão pagar um preço por isso, existe as que querem ficar no trem e não conseguem ficar, aí são aqueles que se tornam aquilo que chamam de "descartáveis". "Descartáveis" são aquelas populações que podem ser, desde população de desempregados dos países ricos, e a gente pode chegar até nas populações indígenas que são populações que não estão nesse tipo, ou quilombolas, que não estão nesse tipo de trem bala. E se a gente levar a sério essa questão da estratégia de aceleração total, econômica e tecnológica, o Heiner Müller vai dizer que vai ser contra as minorias que vai se exercer isso porque justamente a estratégia de aceleração total impõe um ritmo, e esse ritmo tem que ser seguido, e quem não consegue seguir esse ritmo cai fora, cai fora e vai ser processado dentro dessa dinâmica, como, os americanos chamam de loser, quer dizer, perdedores, porque você não consegue acompanhar essa velocidade, e essas populações que não querem entrar ou nunca estiveram nessa, e que já de cara vão ser perdedores como as populações indígenas, justamente as chamadas populações tradicionais, porque as populações tradicionais? 
Porque justamente elas não entraram no movimento moderno e não fizeram a passagem do moderno para o contemporâneo, mas agora elas estão sendo obrigadas a enfrentar isso, em qualquer lugar do planeta que essas pessoas estejam. Eu conheço bem, por exemplo, o povo Yanomami, na Amazônia, e que tem um pedaço desse povo que mora no estado do Amazonas e no estado de Roraima, e tem outro pedaço desse povo que mora na Venezuela, porque esse povo mora em região de fronteira. É floresta fechada, não tem estrada, não tem como chegar lá você só chega de avião pequeno, porque não tem pista, não tem aeroporto pra descer perto das aldeias, então você tem que pagar um vôo de um avião pequeno, e viajar horas por cima da floresta pra poder descer numa aldeia daquelas, $O$ que significa dizer que o acesso é muito restrito, e mesmo assim esse povo que está lá nesse lugar está no mundo globalizado, não tem mais como escapar. Então não existe mais "fora" no planeta, nem com populações tradicionais, o que significa que essas populações tem que enfrentar, lidar com um problema dessa aceleração total de que eu estou falando.

Pra vocês terem uma ideia da aceleração total e não acharem que eu estou exagerando, eu vou ler um pedacinho de uma observação feita por um sujeito que é engenheiro nuclear, chamado Konstantinos Karachalios, ele foi diretor de um projeto que pesquisava o futuro, no escritório europeu de patentes, que é um dos principais organizações internacionais que lida com a questão da invenção e com o patenteamento de invenções, portanto ele está lidando com tudo que é tecnologia de ponta que está sendo inventada, que está sendo produzida, e que está se pedindo pra obter os direitos de propriedade intelectual. Esse escritório, justamente pelo problema que se colocou, eles são cinco mil e tantos funcionários espalhados pela Europa, de altíssimo nível, todo mundo com nível de doutorado para cima, e é um escritório poderosíssimo, pra poder acolher isso tudo, e eles resolveram fazer um grupo de pesquisa sobre o futuro, precisamente porque eles previram a expansão do escritório durante certo tempo, e eles perceberam muito rapidamente que a previsão deles foi rapidamente superada e que na verdade eles tinham que ter previsto uma velocidade três vezes maior do que aquela que eles tinham previsto, portanto que eles tinham que aumentar o seu quadro de pessoal num 
ritmo três vezes superior àquele em que eles estavam funcionando. Então eles constituíram um think tank dentro do Escritório Europeu de Patentes para estudar o que iria acontecer com a tecnologia do ano 2000 até 2030.

Esse mesmo sujeito comentou comigo que ele foi estudar outros grupos de think tanks americanos, europeus, japoneses, e etc., que também estavam estudando questões de futuro e que todos esses outros grupos que também estavam estudando, todos tomavam como horizonte 2030, e ele perguntou para mim: "Você sabe por que 2030 é o horizonte?", e eu falei "não, não sei” e ele disse "é que depois de 2030 é inimaginável”. Só é possível prever alguma coisa sobre a velocidade da aceleração tecnológica até 2030, depois é inimaginável. Eu vou ler um trechinho de um comentário que ele fez sobre o sentido e a potência de aceleração pra vocês terem uma ideia de em que mundo nós estamos, porque isso inclusive que ele escreveu era no ano de 2006, por aí, portanto lá se vão uns oito anos, e no ritmo em que as coisas vão esses oito anos fazem uma grande diferença.

Meu computador, que agora eu vou ter que trocar porque ele já não consegue mais processar, já está ficando velhinho, já está começando a desconectar coisas, etc., pra vocês terem uma ideia ele tem seis anos, e é claro que quando eu falo para as pessoas de hoje que eu tenho um computador de seis anos atrás, ele é Macintosh, mas ele é de seis anos atrás, a pessoa diz "nossa, isso é anti-diluviano! Esse computador, é claro que ele tem que estar obsoleto". E eu também obsoleto junto com ele, é claro, porque eu não me mantive no ritmo que é recomendável. Mas agora eu vou dar um upgrade em mim mesmo e estou dando um upgrade de computador.

Mas o que ele diz lá pelo ano de 2006? É sobre a questão da aceleração tecnológica e seus impactos sobre o humano, afim de se ter uma medida, se é que se pode dizer assim, do impacto e da intensidade da aceleração tecnológica sobre o humano, o Konstantinos diz assim: se você considerar o progresso tecnológico realizado no ano 2000 como uma unidade de tempo tecnológico, então calcula-se que o século XX teve ao todo, dezesseis dessas unidades, todo o século XX é equivalente a apenas dezesseis anos do progresso tecnológico medido pelo ano 2000. Isto é, em termos tecnológicos, o século todo poderia ser comprimido em apenas 
dezesseis anos, com desenvolvimentos cada vez mais concentrados em seu final. Levando em conta esse efeito de aceleração, você poderia imaginar quantas unidades de tempo tecnológico nós e nossos filhos, vamos experienciar e ter que enfrentar durante o século XXI? Aparentemente haverá mais do que cem, mas você pode imaginar quanto? Bem, se você simplesmente extrapolar a tendência atual, assumindo que não ocorrerão desastres em larga escala e a longo prazo, pode ser que tenhamos que lidar com o progresso tecnológico equivalente a vinte e cinco mil anos, baseado na tecnologia do ano 2000. Vinte e cinco mil anos dentro de duas gerações. Mesmo que você considere "apenas" mil anos, teremos que enfrentar desafios semelhantes aos que a maioria das populações da África ainda está enfrentando, populações que foram catapultadas da idade da Pedra ou do Ferro na modernidade dentro de duas, três gerações.

Eu acho que isso é uma questão interessante porque é algo sobre o qual a gente pode pensar e que dá uma medida do que está acontecendo e que dá uma medida que é de certo modo palpável porque ela é calculável e ela tem por referência um metro que é a intensidade tecnológica do ano 2000. Se continuasse no ritmo de 2000, mas não continuou, porque a gente sabe, como eu falei no começo da palestra, que a Lei de Moore está valendo desde 1970, ou seja, a capacidade de cálculo do ano 2000 pra cá, a cada um ano e meio dobrou, portanto a intensidade tecnológica acelerou muito mais do que do ano 2000, portanto esse cálculo mesmo que ele está dando aqui, é modesto perto do que veio depois.

Quando eu fiquei sabendo disto aqui, já faz alguns anos que eu fiquei sabendo dessa história, através do próprio Konstantinos me contando, isso mudou minha vida completamente pelo seguinte: eu tive uma ideia do que é o impacto da tecnologia da aceleração tecnológica sobre nós. Eu trabalhava e estava em contato com índios Yanomami, que são considerados, como essas populações africanas tradicionais, que estão na "Idade da Pedra". Eu acho que eles não estão, porque eles evoluíram por outra via, completamente diferente da nossa, as tecnologias deles são avançadíssimas, mas são xamânicas, elas não são em objetos como as nossas, elas não são incorporadas em objetos, elas são incorporadas no corpo dos xamãs, então são tecnologias - a maneira de acessar mundos 
virtuais - é completamente diferente da nossa, é tão complexa quanto a nossa, porque a gente também não pode achar que só nós evoluímos e que eles ficaram parados, eles que também são humanos e que são inteligentes como nós, que eles ficaram parados. Como diz aqui o texto do Konstantinos, na Idade da Pedra, é claro que eles não ficaram parados, eles ficaram parados na Idade da Pedra com relação à nossa tecnologia, mas com relação à tecnologia deles, pode ser até que nós estejamos, mesmo com essa velocidade toda, a gente esteja do ponto de vista deles subdesenvolvidos, visto por outra ótica, é outro ponto de vista, outra perspectiva.

Como a gente mede tudo pelo nosso metro de evolução tecnológica a gente acha que eles são arcaicos, atrasados, portanto tradicionais do passado, mas de repente eles são contemporâneos da gente numa outra chave que a gente nem está sabendo qual é porque as tecnologias deles não são reconhecíveis por nós, assim como as nossas não são reconhecíveis por eles, mas se for mútua a história de repente eles evoluíram numa outra chave, e talvez seja interessante a gente se perguntar que chave é essa antes de acabar com eles, e dizer: "ah isso aqui tem que desaparecer, porque como eles são uns atrasados duns povos pré-modernos, duns caras arcaicos que só estão aí enchendo a paciência e impedindo que o agro-negócio acabe com toda a diversidade biológica e plante só soja na Amazônia inteira, eles tem que acabar, tem que desaparecer, tem que fazer a chamada limpeza étnica e social".

Isso a aceleração total faz, limpeza étnica e social, pois como diz o Müller, quando você impõe uma ditadura de um determinado ritmo, de uma determinada velocidade, aqueles que resistem a viver neste ritmo e nessa velocidade, tem que desaparecer, você tem que fazer a limpeza deles, tirá-los da frente porque eles estão atrapalhando, eles se transformam em obstáculos. Isso é importante também, da gente entender por que é que as leis de imigração na Europa são o que são e estão piorando cada vez mais, por que a extrema direita está ganhando terreno em todo lugar, porque tudo que for população que está atrapalhando essa velocidade tende a ser neutralizada, para dizer o mínimo, para depois, num segundo momento, serem eliminadas e É a chamada limpeza étnica e limpeza social, que é o 
que a gente está fazendo com os índios aqui desde 1500, mas que a gente quer fazer até o fim, levar esse processo até o final. Eu acho interessante essa observação do Karachalios para dar uma ideia para nós sobre a questão da aceleração porque ele usa um termo de comparação com povos tradicionais africanos, e eu estou usando com povos tradicionais indígenas do Brasil, mas ele não está falando com relação a povos tradicionais, ele está falando com relação a povos modernos e contemporâneos, porque ele está falando de nós. Ele está falando: 25 mil anos, duas gerações vão ter que enfrentar em termos de aceleração tecnológica, vão ter que enfrentar e vão ter que lidar com, e é a população ocidental digamos "evoluída". Ou seja, uma população que tem que lidar com o impacto de uma velocidade que nos transforma em primitivos dentro de nossa própria cultura, dá para entender o que eu estou falando?

Quando a turma começa toda a se tatuar, começa todo mundo a querer achar seu traço minoritário distintivo como se fosse um neoprimitivo, isso é apenas um efeito de superfície de algo muito maior que está por trás. As pessoas não sabem que elas querem, ou que elas começam a escolher suas tribos, e começam a falar em tribo, mas qual é que foi o movimento que começou a ser realizado que fez com que as pessoas começassem a procurar traços identitários em tribos, de certa maneira, e tribos urbanas, e tribos de faixa etária, e tribos que vão fazer rolezinho, tribo disso ou daquilo, tatuagem assim, efeitos de diferenciação assado e etc. É claro, porque diante de um rolo compressor que, digamos, nivela e homogeneiza tudo, você vai procurar estabelecer algumas diferenças, para tentar fazer alguma diferença, porque senão, do ponto de vista da aceleração total, não tem diferença, ou se tiver vai ser para eliminar a diferença, porque você vai ter que ser parecido com aquilo que o processo diz que é o desejável, que é o que precisa ser adotado.

Eu acho interessantíssimo, porque isso é um efeito, digamos, se na nossa própria cultura a gente se transforma em neo-primitivos, isso significa que a gente também tem um impacto gigantesco. Imagina o impacto cultural disso, o impacto de parâmetros e o impacto na percepção e o impacto na sensibilidade das pessoas e é claro que esse impacto vai ser cada vez maior. Como lidar com isso? Eu não vou ficar falando aqui, 
mas eu fiz um estudo a respeito, que era uma coisa que me interessava e continua me interessando, era sobre a chamada obsolescência do humano nesse processo. Quem são as pessoas que estão estudando a obsolescência do humano diante deste ritmo? Tem escolas de pensamentos diferentes discutindo essa questão, e eu acho que era uma questão que em um curso de ciências sociais é importante saber que existe. É importante saber que existe porque é preciso que as pessoas saibam que, digamos, quando ela não dá conta do ritmo no qual ela está inserida, em geral a sociedade a criminaliza de certa forma, se você não dá conta você que é culpado, você não dá conta porque você é fraco e você que é culpado, quer dizer, é individualizada a questão.

Mas se for um fenômeno social, e o Konstantinus está mostrando aqui pra gente que é um fenômeno planetário, se é um fenômeno planetário, então o problema, por exemplo, da desempregabilidade das pessoas, o fato de elas não acharem mais emprego ou de não existir mais emprego para elas, ou da chamada "crise da sociedade do trabalho" não é um problema que deve ser considerado ou atacado do ponto de vista da fraqueza de cada um ou da força de cada um, e é um fenômeno social digamos global, e é o processo que dita que essa descartabilidade vai aumentando cada vez mais, e que, portanto a possibilidade de encontrar um emprego diminui. Mesmo porque os empregos vão sendo eliminados porque só vão continuar existindo os empregos que são criados dentro do trem-bala, sejam eles permanentes, sejam eles temporários, e cada vez mais tem emprego temporário dentro do trem-bala, também isso é uma característica que não vou mexer, por que estou só pontuando para chamar atenção.

Então, essa avalanche, da qual eu estava falando, eu acho que é interessante porque, justamente, torna a gente primitivo dentro de nossa própria cultura, e ser primitivo dentro da sua própria cultura é uma questão, no meu entender, do ponto de vista político, isso tem uma incidência gigantesca sobre o que se entende por política.

Quando Richard Buckmister Fuller, que descobriu a aceleração da aceleração e que descobriu o impacto da miniaturização nos anos 1970, começou a estudar a questão da tecnologia, foi nos anos 1920, nos 
Estados Unidos, faz quase 100 anos. Esse sujeito teve um problema, ele perdeu uma filha, ele tinha vinte e poucos anos, (ele era inteligentíssimo evidentemente), e entrou numa crise brava e tentou se suicidar se afogando num lago. Ele não conseguiu, e aí se fechou em casa durante dois anos, apenas com a obra de dois grandes homens: com a obra de Einstein e com a obra de Leonardo da Vinci. Um artista, um cientista. Ele ficou dois anos sem falar com ninguém e estudando o Leonardo da Vinci e estudando o Einstein, e dois anos depois ele saiu. E quando saiu ele fez um comentário que eu acho interessante, que é justamente sobre a relação entre tecnologia e política. Ele disse o seguinte, que ele ia desistir da política, e ia passar a concentrar toda a sua atenção na tecnologia, ele ia desistir da política porque na política você tenta fazer a cabeça do outro, você tenta convencer o outro e conscientizar o outro a mudar, e ele diz que pensando bem depois desses dois anos, ele tinha descoberto que em vez de ficar tentando convencer o outro a mudar, se você mudar o entorno, o meio no qual o outro está vivendo, a cabeça dele mudava junto. Então em vez de você ficar tentando convencê-lo a mudar, você introduzia no meio dele outro tipo de relação, e ao introduzir outro tipo de relação à cabeça dele mudava junto. Eu acho isso interessantíssimo como observação à luz de tudo que está acontecendo da década de 1970 pra cá, eu acho que de certo modo, e aí é uma provocação que eu faço aqui: A Universidade ensina muito pouco sobre o mundo contemporâneo, eu acho que a gente aprende muito mais com as tecnologias do que com a Universidade eu sou professor universitário, fui trinta anos professor universitário, mas eu estou convencido de que na Universidade a gente aprende pouco, sobretudo depois que as tecnologias e os meios de informação tornaram acessível à informação e o conhecimento numa escala inaudita, nunca no mundo foi possível acessar o que se pode acessar hoje.

Eu vou dar um exemplo pequeno para mostrar pra vocês como é que hoje, se a gente souber procurar e souber o que a gente quer procurar, você tem acesso ao conhecimento universal inteiro, em vez de ficar no facebook acessando fofoca o dia inteiro, porque também você pode usar a tecnologia para fazer fofoca o dia inteiro, perder o seu tempo literalmente, você pode perder seu tempo o dia inteiro se você quiser, claro, mas você 
pode fazer outra coisa com ele também. Eu estou fazendo uma exposição em São Paulo de um pintor brasileiro pouco conhecido, ítalo-brasileiro. E esse homem morou no Brasil até os vinte anos de idade, depois ele foi para a Itália, ficou dos vinte aos quarenta e oito anos na Itália, ele era pintor de parede, num tempo que pintor de parede não era só o cara que pegava o pincel e pintava de branco uma parede. Era um tempo em que as pessoas sabiam fazer imitação de mármore, imitação de madeira, sabiam fazer stock, sabiam fazer digamos uma séria de chamada pintura decorativa. Esse sujeito era pobre e foi para a Itália, morar perto de Florença e começou a entrar em contato com a pintura do Renascimento Italiano. O acesso era fácil porque era só entrar nas Igrejas e ver, não precisa pagar nada, era só começar a ver. Como ele conhecia bem fazer tinta, o preparo da parede, etc., ele começou a estudar os afrescos das Igrejas e depois ele começou a utilizar isso, todo esse conhecimento apreendido, ele começou a utilizar na pintura dele. Depois que voltou ao Brasil, ele pintou de 1948 até 1995, quando morreu aos 95 anos de idade. Por que eu estou contando isso? Porque eu fui fazer essa exposição, e como curador dessa exposição eu queria mostrar a importância desse pintor, e eu queria dizer que ele era um grande, e pra eu poder dizer que ele era grande eu precisava saber que técnicas ele usava. Para levar alguns trabalhos dele que precisavam ser "higienizados" como eles dizem, precisava limpar, porque tinha uma camada de sujeira em cima da pintura, eu fui a um restaurador, sujeito que conhecia as técnicas antigas e modernas começou a falar: ele mistura técnicas antigas e modernas de uma maneira incrível, ele faz as próprias tintas, ele era pobre então ele faz as telas, ele faz tudo, na pintura dele, ele não compra nada, e pra poder fazer isso, ele tinha um conhecimento enorme dos tratados dos pintores de 1400, 1450, 1470. O restaurador falou pra mim: leia os tratados, para você ver se eu não tenho razão. Eu tinha um prazo para escrever um texto pro catálogo, eu fui pra casa, entrei na internet e eu acessei os tratados todos, de 1400. Estavam lá os tratados em italiano, todos contavam como é que faz, quanto você põe gema de ovo, quanto você faz não sei o quê, quanto você faz isso, quanto você faz aquilo, como é que você faz o afresco, quando você faz claro e escuro pra obter efeito de luz, como é que você usa a cor como luz, você muda de 
cor, mas você faz de tal jeito que você pinta um pedaço da casa que está virado pra cá com uma determinada cor, e parece que a casa está tomando sol, porque aquela face da casa está no sol, mas você mudou de cor e etc. Mas isso eram técnicas de 1400 . As pessoas, nem tinha perspectiva ainda, nem perspectiva existia ainda a perspectiva central, do Renascimento, que os próprios italianos inventaram 100 anos depois. E é interessantíssimo, como é que eu pude fazer isso, sem gastar um tostão? Eu pude fazer isso porque evidentemente eu posso acessar pela internet esses tratados todos, esse conhecimento está aí.

Isso que faz com que um prêmio Nobel de Literatura como Elias Canetti diga, na década de 1960, antes da internet, (mas ele já estava sacando qual era a direção que as coisas estavam indo): "nós temos que lidar com uma realidade crescente, e essa realidade crescente significa uma realidade ampliada, por que, o velho está sendo desenterrado, cada vez mais acessivel, o novo está sendo cada vez. mais acelerado". O novo, ele estava querendo dizer: toda a cultura tecnológica que estava vindo, e ele já estava vendo. E o diferente também, por diferente ele queria dizer os povos tradicionais, que são completamente diferentes de nós, que tem um modo de existência e um modo de conhecimento completamente diferente do nosso, e esse diferente também faz parte dessa realidade crescente. Quando a gente começa a olhar o diferente a gente começa a perceber uma coisa, que o diferente é o que ainda mantém a capacidade de invenção, porque a capacidade de invenção surge onde existe mito, a sociedade moderna não tem mais mito, nós não temos mais a capacidade de inventar, se vocês forem considerar, diz ele, todas as tecnologias de hoje, e se vocês forem ver a origem dessas tecnologias, vocês vão descobrir que antes delas serem concretizadas e de existirem concretamente como máquinas, elas foram descobertas e inventadas no tempo do mito, e o tempo do mito que é o único capaz de invenção, faz com que eles consigam todas as máquinas de hoje são baseadas em coisas que foram pensadas lá pra trás, nós não temos mais a capacidade de inventar mitos, e não tendo a capacidade de inventar mitos todas as máquinas que a gente tem e que a gente faz evoluir são máquinas baseadas nos mitos antigos, a começar do avião, evidentemente. 
Tem mais, então, portanto esses povos e essas culturas tradicionais são importantíssimas, por um lado, por outro lado ele diz que os diferentes não são só sociedades humanas, são também as sociedade animais, portanto as não humanas, e diz se há alguma coisa que a gente está começando a descobrir, é que as sociedades animais são tão complexas quanto as sociedades humanas, e nós estamos começando a entender as sociedades animais. E aí eu entro na questão justamente das tecnologias indígenas, por exemplo. Para os Yanomami, assim como para todos os povos da América tradicionais, todo o saber do humano vem através de espíritos humanimais, que dividiram com os humanos uma primeira humanidade lá pra trás que a gente poderia chamar de "dimensão virtual da realidade". Do ponto de vista Yanomami, a onça também tem uma sociedade, as formigas tem uma sociedade, as antas tem uma sociedade, os pássaros tem sociedade também. Antes de eles serem naturais eles são sociais. Eu acho interessante que o Canetti tenha chegado lá na via das sociedades dos animais e dizer que o interessante é a gente começar a ver não só esses povos que seguiram outros caminhos e que tem outras perspectivas diferentes das nossas e que existem no tempo do mito, e que pensam o mito, e que tem capacidade de invenção, coisa que a gente não tem mais, porque nós estamos concretizando aquilo que os antepassados no tempo mítico sonharam e pensaram. E por outro lado, de agregar as sociedades animais, porque muito do conhecimento das sociedades tradicionais indígenas vem, ou quase todo, ou todo, vem através do que os espíritos humanimais contam para os xamãs. E se esses espíritos que são humanimais contam, é justamente a partir de uma perspectiva em que eles podem falar com os animais, os xamãs podem falar com os animais porque eles tem um ponto de vista comum, e a partir de uma linguagem comum eles podem se entender com os animais que transmitem a eles conhecimentos que eles vão trazer para o mundo desta humanidade que está aqui. Eu acho isso interessantíssimo, e gostaria de encerrar só com mais uma observação, e aí agora não é mais com relação ao tradicional, mas com o contemporâneo e o ultra-contemporâneo na política.

Um dos aspectos, digamos, do arcaísmo no qual, apesar da velocidade da sociedade que a gente vive, da sociedade transformada que a gente vive, 
aparece, é o modo como os jornais lidam com a política. A rubrica política nos jornais, política nos jornais é aquele mercado de compra e venda de interesses dentro do legislativo ou da relação entre legislativo, executivo, e agora o judiciário também. Isso é a chamada política. Eu acho que a política não passa mais por aí, esse mundo da representação da política é cada vez mais ultrapassado ou de certo modo desviado por um poder real que passa por outras vias, que passa por vias de redes, que passa por vias de redes financeiras poderosíssimas, que passa por vias de redes de espionagem poderosíssimas, e é nesse ponto que eu queria chegar, de redes de transmissão e produção de conhecimento que são poderosíssimas. No meu entender os heróis políticos de hoje, e os heróis tout court, os heróis mesmo, não são nem Neymar, nem Dilma, eu diria até, nem Lula, no meu entender, os heróis políticos de hoje se chamam Assange, se chamam Snowden, se chamam Aaron Swartz, aquele sujeito que se suicidou nos Estados Unidos com 26 anos de idade porque o Governo Americano conseguiu uma condenação que ele tinha que pagar um bilhão de dólares porque ele montou dispositivos fantásticos de transmissão gratuita de conhecimento para o Planeta inteiro, e por isso mesmo ele foi punido a ponto de ter uma dívida impagável e ele se matou. Apesar de ser um enorme talento, ele se matou porque ele não conseguia pagar um bilhão de dólares que era a condenação que ele teve. Essas figuras para mim são os heróis políticos contemporâneos.

Eu gostaria de encerrar com um pequeno comentário do Assange sobre, justamente, o que é a produção de conhecimento contemporâneo e o que é fazer política no contemporâneo. Foi uma entrevista que ele deu, e que agora já não é mais secreta, na época que eu acessei isso era confidencial, era um livro sobre justamente o que vai acontecer na tecnologia nos próximos 10 anos, que o presidente da Google estava fazendo e ele foi entrevistar o Assange quando o Assange estava sendo processado na Inglaterra antes dele pedir seu asilo na embaixada do Equador, em Londres. Esse sujeito foi lá, ele se chama Eric Shimidt, que é o presidente da Google, e conversa vai conversa vem o Assange começou a falar sobre como é que era essa moçada hacker da Internet e o que ele considerava que estava acontecendo com essa moçada backer da internet e com esses dispositivos justamente 
de fazer proliferar a informação importante, e fazer proliferar justamente, abrir transparência pra tudo aquilo que os centros de poder econômico e político tentam manter secreto. Abrir isso e jogar nas redes. E o Assange disse assim:

"Isso é a coisa mais otimista que está acontecendo, a radicalização da juventude educada da Internet, as pessoas que estão recebendo seus valores da Internet, e então, na medida em que acham que esses valores são compatíveis, ecoam de volta, correspondem. Agora, o eco de volta é tão forte que ele submerge às afirmações iniciais (que partiram da Internet) completamente. As pessoas com quem tive que lidar, dos radicais dos anos 1960, que ajudaram a liberar a Grécia e Portugal (Salazar), eles estão dizendo que esse momento no tempo é o mais similar ao que aconteceu no período dos movimentos de liberação dos anos 1960, o mais similar que jamais viram. Aí, o sujeito que está ouvindo, diz pra ele assim: "Você o vê adquirindo uma escala diferente da que teve nos anos 1960?". O Assange responde: "no tocante ao que aconteceu no Ocidente, porque há certas regiões no mundo que eu desconheço, mas no tocante ao que eu sei, e é claro, eu não existia nos anos 1960 (porque ele é jovem), mas o que posso dizer é que essa afirmação é verdadeira, trata-se da educação política de uma gente técnica apolítica. É extraordinário, do mesmo modo que os jovens (...)"

(O outro interrompe e diz) "Apolítica? Você quer dizer essa palavra? Apolítica?"

O Assange responde: "Essa palavra. As pessoas estão passando, os jovens estão passando do apolítico para o político, é uma transição muito interessante de se ver". Eu acho isso interessantíssimo porque ele diz que é a internet que está politizando a juventude educada da internet. A internet, politizando essas pessoas, porque do ponto de vista tecnológico, a rede está abrindo possibilidades pras pessoas fazerem política: compartilhamento de software, abertura de conhecimentos, foco em cima de tudo aquilo que os poderes constituídos querem esconder, e que você pode revelar, e etc, e por isso que eu falei que os heróis de 
hoje são Assange, Snowden e etc. Essa possibilidade vem da possibilidade tecnológica dessas tecnologias da informação. E essa possibilidade, faz com que esses jovens se politizem junto com os aparelhos, juntos com esse ambiente que está criado, e a partir do qual eles podem operar e com o qual eles podem operar, fazer política de um modo diferente. Eu acho isso interessantíssimo, inclusive quando a gente vai ver, por exemplo, (mas isso a gente não encontra nos jornais brasileiros, se vocês lessem o Financial Times, que é o jornal dos ricos do mundo, do mundo globalizado, eles dizem, por exemplo: "Snowden é uma figura ícone da geração globalizada", "A saga de Snowden anuncia uma mudança radical no capitalismo".

Isso são os artigos que são vários, eu peguei dois, só para dar o exemplo aqui, são artigos que são publicados no jornal Financial Times de Londres tentando justamente entender o que essas figuras estão fazendo, mas tentando entender isso para mostrar para os ricos, porque os ricos, justamente, tem que defender o interesse deles, eles já estão com a alta tecnologia, eles já operam no mercado financeiro com alta tecnologia, e eles pra se proteger evidentemente estão fazendo isso. Mas esses caras não estão fazendo isso, eles não estão trabalhando para os ricos, eles estão fazendo política de um outro modo, e eu acho que é preciso começar a prestar atenção neste outro modo de fazer política com as máquinas, e fazer política com as máquinas não é fazer política só operando com as máquinas mas é entendendo as lógicas que estão nas máquinas e a potência que essas máquinas tem, que junto com a potência do Humano, em uma articulação nova, podem fazer alguma coisa acontecer. É isso, obrigado. 
